University at Buffalo School of Law

Digital Commons @ University at Buffalo School of Law

\title{
Beyond Westphalia: Competitive Legalization in Emerging Transnational Regulatory Systems
}

\author{
Errol E. Meidinger \\ University at Buffalo School of Law, eemeid@buffalo.edu
}

Follow this and additional works at: https://digitalcommons.law.buffalo.edu/book_sections

Part of the Environmental Law Commons, International Law Commons, and the International Relations Commons

\section{Recommended Citation}

Errol E. Meidinger, Beyond Westphalia: Competitive Legalization in Emerging Transnational Regulatory Systems in Law and Legalization in Transnational Relations 121 (Christian Brütsch \& Dirk Lehmkuhl, eds., Routledge 2007)

This is an Accepted Manuscript of a book chapter published by Routledge in Law and Legalization in Transnational Relations on 02/08/2007, available online: http://www.routledge.com/9780415423281

\section{IN COPYRIGHT}

This Book is brought to you for free and open access by the Faculty Scholarship at Digital Commons @ University at Buffalo School of Law. It has been accepted for inclusion in Contributions to Books by an authorized administrator of Digital Commons @ University at Buffalo School of Law. For more information, please contact lawscholar@buffalo.edu. 


\title{
Beyond Westphalia: Competitive Legalization in Emerging Transnational Regulatory Systems ${ }^{\circ}$
}

\author{
Errol Meidinger“
}

\begin{abstract}
This paper analyzes several emerging transnational regulatory systems that engage, but are not centered on state legal systems. Driven primarily by civil society organizations, the new regulatory systems use conventional technical standard setting and certification techniques to establish market-leveraged, social and environmental regulatory programs. These programs resemble state regulatory programs in many important respects, and are increasingly legalized. Individual sectors generally have multiple regulatory programs that compete with, but also mimic and reinforce each other. While forestry is the most developed example, similar patterns are evident in agriculture, fisheries, apparel, and mining, among other sectors.

The paper describes the institutional structures and routines of the new regulatory systems, their interactions with state based systems, and some possible broader implications for law and society. Among other things, it notes that the emerging regulatory systems permeate their sectors with increasingly broad and deep rule systems and seek to remain highly dynamic at the same time. The paper closes with a brief discussion of whether the systems might be sketching the outlines of new forms of transnational democracy.
\end{abstract}

Keywords: certification, democracy, environmental law, environmental management, fisheries, forestry, globalization, human rights, international law, legalization, legal pluralism, mining, organic agriculture, participation, polyarchy, regulation, socio-legal studies, standardization, sustainable development, sweatshops, transnational society, transparency

- Submitted for future publication in Christian Brütsch and Dirk Lehmkuhl, $\underline{\text { Hard, Soft and Private }}$ Legalities: The Increase, Variation and Differentiation of Law-Like Arrangements in International Relations (forthcoming).

- Professor and Vice Dean of Law for Research, Adjunct Professor of Sociology, State University of New York at Buffalo, 14260 (eemeid@buffalo.edu) and Honorary Professor of Forestry and Environmental Science, University of Freiburg, Germany, 79106. Distinguished Environmental Scholar, Lewis and Clark Law School, 2006-2007. 


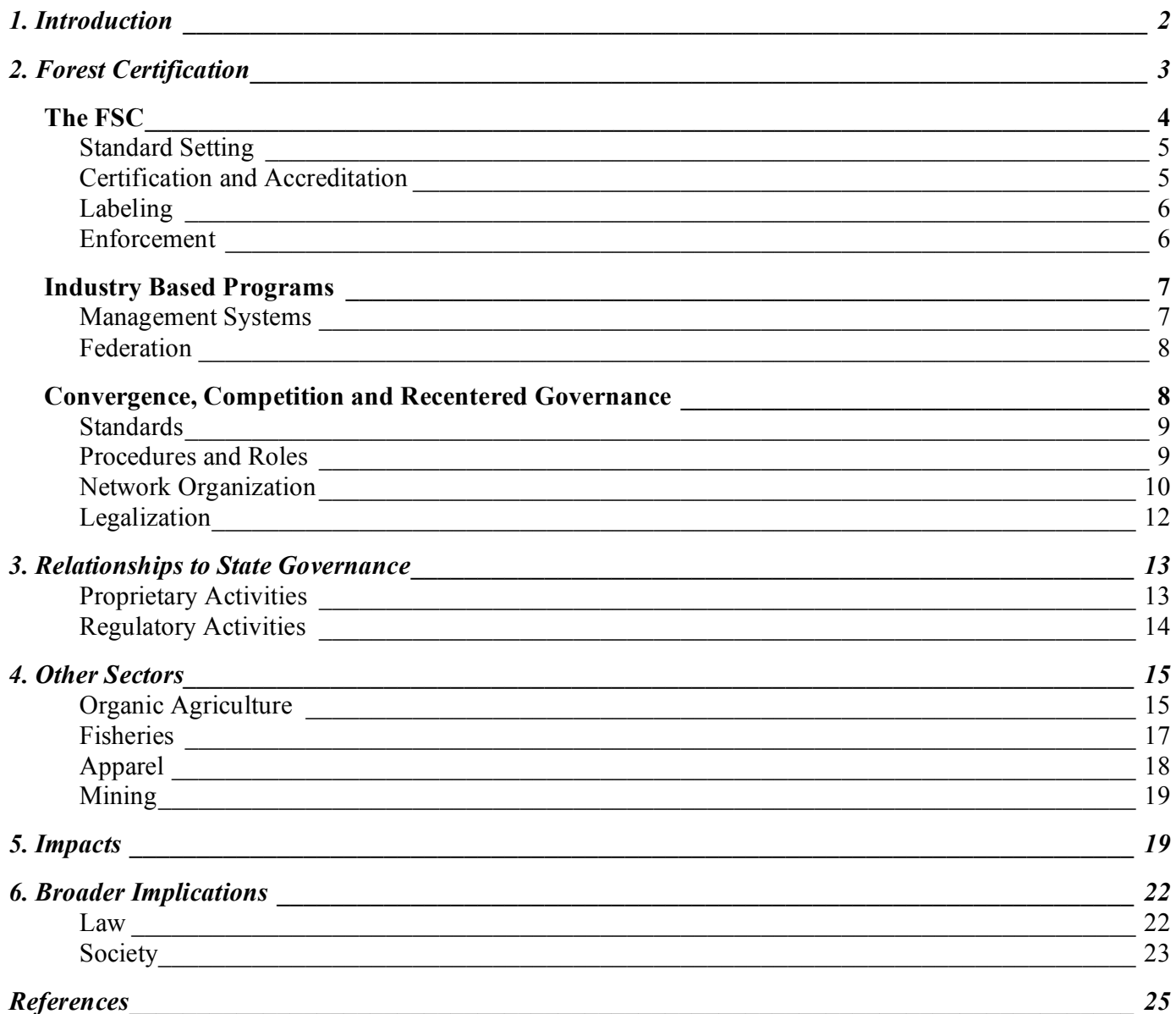

\section{Introduction}

Remarkable new supra-governmental, transnational regulatory systems are taking shape around us. Driven primarily by civil society organizations, but also by governments and industry associations, these systems draw on conventional technical standard setting and certification techniques to establish market-leveraged, social and environmental regulatory programs. They go beyond traditional standard setting, however, in seeking to protect interests not directly involved in the market chain. Moreover, these systems incorporate plural rule-making, adjudication, and enforcement programs. The programs constantly compete with, but also mimic and reinforce each other. While the most developed example is in forestry, similar systems are also present in agriculture, fisheries, apparel, and mining, among other sectors. They share the assumptions that enterprises around the world should be held to common standards and that compliance with those standards can be assured through use of formally independent expert auditors. The various standards, procedures, 
and roles of the actors are generally defined in terms of formalized rules, rights, and duties based on normative criteria in ways very similar to those of state based legal systems.

This paper examines forestry regulation as a central case but also draws parallels to the other sectors mentioned above. 'Regulation' here means simply a purposive, organized and sustained effort to establish a general and consistent order in a field of human activity (e.g., Black 2002). Since it typically centers on rules defined in terms of rights and duties, with differentiated official roles and normative justifications, regulation is a form of law, but one that is characterized by a reliance on credentialed experts who are expected to manage a field and to learn and adapt based on experience.

This paper first describes the forest certification regulatory system and the process by which it has been established (Section 2), next discusses its relationship to state governance systems (Section 3), makes some comparisons to other sectors (Section 4), and finally considers the impacts (Section 5) and possible broader implications for law and society (Section 6 ) of certification-centered transnational regulatory systems. Overall, it describes a set of multi-centered, competitive regulatory systems that are increasingly rule-permeated and changeable at the same time. The paper closes with a brief discussion of whether these systems might be sketching the outlines of new forms of transnational democracy.

\section{Forest Certification}

Forest certification was instituted by a loose-knit group of extragovernmental 'regulatory entrepreneurs' (see Meidinger 1985) in response to the failure of the Westphalian system to curb rapid tropical forest destruction, a process that came to be understood as reaching crisis dimensions in the 1980s (Humphreys 1996; Gale 1998). While there are multiple reasons for tropical deforestation, a major one has been the burgeoning importation of tropical timber by developed countries wanting cheap wood (Brown 2001).

Exasperated with the failure of intergovernmental negotiations to effectively address the problems of tropical ecosystem destruction and biodiversity loss, some Northern environmental groups pursued a tropical timber boycott, but dropped it when its potentially perverse consequences of hurting proper tropical forest management and possibly speeding agricultural conversion because of the decreased economic value of forests became apparent. As an alternative, they tried to get the intergovernmental system, via the International Tropical Timber 
Organization (ITTO), to establish a system for certifying sustainably produced timber so that it could be distinguished and rewarded in international markets. The idea was to convert the rapidly growing global timber market into an engine of forest preservation, rather than destruction. The ITTO, which consists of approximately 40 of the largest tropical timber exporting and importing countries, refused to establish such a system. Several Southern exporting countries evidently saw it as a potential non-tariff barrier to trade in that northern environmental groups might call for boycotts of non-certified timber.

As early as 1989 the non-profit US-based Rainforest Alliance established its own program for certifying sustainable tropical timber - 'SmartWood'. While many of the larger environmental groups continued to pursue intergovernmental regulatory solutions, they also began laying plans for what they saw as the distinctly inferior option of establishing a freestanding non-governmental forest certification system. After the 1992 UN Conference on Environment and Development (UNCED) in Rio failed to achieve a binding forest convention these plans were put into motion with the 1993 founding of the Forest Stewardship Council.

\section{The FSC}

Although discussions of creating an umbrella forest certification system went back at least to 1990, the FSC faced a daunting set of challenges. As suggested above, the FSC was founded by a small progressive coalition of transnational environmental NGOs - primarily the Worldwide Fund for Nature (WWF) and Greenpeace - together some high end wood buyers, progressive foresters, and social activists. Most of the major powers in forestry at the time were absent and many were hostile. Moreover, nothing like a global system for certifying forest management practices had ever been attempted. On the other hand, the standard institutional methods of technical standard setting and certification were available. So too were a professional forestry credo laying out the basic elements of proper forestry and an emerging discourse of sustainable development stressing a the interdependence of economic development, environmental protection and social justice and the importance of using participatory policy mechanisms. Moreover, forestry had long been a relatively self-governing industry and had developed reasonably effective methods of imposing 'sustained yield' forestry in most developed countries, although these had recently been shown to leave out key environmental and social concerns in many cases. 


\section{Standard Setting}

The FSC is constituted as a global, non-governmental, multi-stakeholder organization, reflecting the ascendant canon that effective organizations must incorporate the voices of all interests relevant to their missions. It is governed by a 'General Assembly' organized in three chambers, environmental, social, and economic, each with equal voting power (see generally FSC 2006). The chambers are further subdivided into 'Northern' and 'Southern' sub-chambers, again with equal voting power, to counterbalance the relative overrepresentation of northern interests. Day to day management is delegated to an Executive Director who works in close collaboration with a nine-member elected Board of Directors. Membership in the FSC is open to all organizations and individuals who subscribe to FSC's mission (providing responsible management of the worlds forests) and are endorsed by two existing members.

Shortly after its founding the FSC promulgated a set of 'principles and criteria' (P\&C) intended to govern proper forest management worldwide. Bringing together tenets from forestry, environmental, and human rights discourses, the $\mathrm{P} \& \mathrm{C}$ require compliance with applicable laws and treaties, clear and adequate property rights, protection of indigenous, community, and worker rights, full and efficient use of forest resources, and fairly stringent environmental protection, among other things. These requirements have been revised in limited ways over time and are given further place-appropriate content in national and regional standard setting processes.

\section{Certification and Accreditation}

Much of the FSC's early work focused on accrediting and overseeing the certification organizations whose job it is to ascertain and publicly verify that certified companies in fact comply with the P\&C as well as any applicable national or regional standards. While certification organizations are formally independent of the FSC, the quality of their work and their public credibility are crucial to the success of the FSC program. A typical FSC certification process includes, among other things, (1) an intensive site visit by a team of certifiers possessing forest management, environmental, and social expertise and seeking to ascertain compliance with the full array of applicable standards (but with latitude to grant certification despite minor shortcomings), (2) consultations with local stakeholders, (3) preparation of a draft report which is subjected to peer review by two or three external experts, (4) discussion of possible terms of the certification with the applicant, including possible pre-conditions or corrective actions to be taken within a specified amount of time, (5) an official certification decision including final preconditions or corrective action requirements, (6) a public summary of the decision containing 
'sufficient information to make clear the correlation between the specific results of the certification assessment and FSC principles', (7) annual audits, and (8) a full review for possible renewal every five years.

Certifiers thus combine the traditional public law functions of administrative inspection and adjudication, but their services are paid for by the by the applicants for certification. The risks of corruption posed by this arrangement do not seem to have been a major concern of the FSC system early on, evidently because of the faith in professionalism that characterizes the forestry sector and the assumption that, if anything, certifiers were likely to be too tough in doing the bidding of what was perceived to be a zealous certification program. Nonetheless, the FSC set up a system for auditing certification decisions and has suspended the accreditation of certifiers on a few occasions. Over time the accreditation and auditing program has become more formalized, and it was recently made financially independent of the FSC.

\section{Labeling}

The FSC also developed standards for certifying the 'chain of custody' of certified products. The original goal was to be able to prove that the wood in any product carrying the FSC logo actually came from a certified forest. This can be quite complicated in the highly differentiated, multi-supplier, long distance, high volume, and low margin markets that characterize the modern forestry sector. Over time the FSC certified content requirements have become considerably looser, allowing certain products to carry the logo based on a set percentage of FSC content.

\section{Enforcement}

While the FSC certification program was initially scorned or ignored by most established forestry powers, it soon came to be perceived as a force to be reckoned with. One of the most important reasons was a series of campaigns by environmental activists to pressure major wood products retailers to commit to buying FSC certified wood. British do-it-yourself retailer $\mathrm{B} \& \mathrm{Q}$ quickly welcomed the FSC as a way of responding to activist criticisms of its purchasing policies that predated the FSC's founding. American retailer Home Depot joined after several hundred well publicized actions by the Rainforest Action Network (RAN) in its parking lots and stores threatening to associate the Home Depot brand with rainforest destruction (e.g. Sasser 2002). By thus focusing on key retailer links in the extended global forest product chain activist groups were able to use market relationships to leverage the FSC into an important new role in forest governance. Leveraging market chains has become a primary enforcement mechanism, although the official mechanisms include 
unannounced inspections, random auditing, and potential loss of certificates.

\section{Industry Based Programs}

Although surprised and often offended by the rise of the FSC, many traditional forestry interests responded quickly. North American industry groups in particular were already worried about their declining public image and promptly decided to establish their own forest certification programs, the Sustainable Forestry Initiative (SFI) in the US and the Canadian Standards Association (CSA) Forest Management standard in Canada (see generally Cashore et al 2003). Program details and histories are too complex to be recounted here, but the broad outlines are clear. Both initiatives sought to develop programs that were acceptable to the public but minimally onerous to industry. The SFI was established by the largest forest products association in the US, the American Forest \& Paper Association (AF\&PA), on its own motion. The CSA was established by the Canadian national technical standard setting body in cooperation with the Canadian forest products industry.

\section{Management Systems}

Although there were many differences between the programs, they both favored the 'environmental management system' (EMS) approach that had recently been developed by the International Organization for Standardization (ISO) in its ISO 14000 series of standards (ISO 2006). This approach relies on 'installing' an EMS in the firm which provides mechanisms to (1) assess the environmental aspects of the firm's operations, (2) plan which ones to improve and how, (3) set measurable goals for improvement, and (4) assign responsibilities for implementing, monitoring, correcting failures, and revising plans to specific individuals. In addition, flowing from the 'total quality management' movement of the 1980s, the EMS approach requires 'continuous improvement' in the management system. Its stress on fully assessing the environmental aspects of the firm's activities expands upon the 'environmental impact assessment' concept originally developed for public environmental management, and may be particularly important for firms operating in unfamiliar environments, as is often the case for global corporations.

The EMS approach differs from the 'performance standard' approach adopted by the FSC in that the firm, rather than the external standard setting organization, is primarily responsible for setting its goals. Moreover, what is audited is the presence of management programs to pursue those goals rather than their achievement. The management systems themselves seem to 
involve an intensification of internal rules, since auditors generally for documentation of procedures and responsibilities, and for documentary evidence that they are being carried out.

\section{Federation}

Industry based programs were also established in a variety of other countries, including the major exporters of Malaysia, Brazil and Indonesia. With the partial exception of the Indonesian program, which is coordinated with the FSC, they all tended to see themselves in opposition to the FSC, which they perceived as too environmentalist dominated and stringent. In 1998-1999 a Europewide federation of forest certification programs was established. The Pan-European Forest Certification Council (PEFC) defined itself not as promulgating a single standard to be deployed worldwide, but rather as providing a common framework for the mutual recognition of nationally based certification programs operating to verify the sustainable forest management practices that were believed already to exist in most European countries. Institutionally and conceptually, it drew heavily on the experiences of the existing certification programs as well as criteria and indicators that had been produced by intergovernmental processes such as a series of Ministerial Conferences on the Protection of Forests in Europe that started in 1990 and continue to the present.

In 2003, PEFC went global, renaming itself the Programme for the Endorsement of Forest Certification. It currently includes 32 nationally based programs, of which 22 have been officially endorsed (PEFC 2006). Although they vary considerably, PEFC programs tend to be more lenient than FSC ones, not only in terms of standards, but also in terms of inspection and chain of custody requirements. They thus tend to be less expensive to participate in and appeal particularly to smaller land owners.

\section{Convergence, Competition and Recentered Governance}

The field of forest certification thus centers around two primary alliances.

On one side is the FSC with its orientation to relatively uniform performance standards, including environmental and social concerns, providing for low discretion on the part of firms and certifiers and a high degree of multi-stakeholder control. On the other is the PEFC alliance, with its preference for procedurally oriented management system standards, focused primarily on locally defined best forestry practices, high discretion, and a high degree of landowner and business control. And 
yet, the systems have also developed a growing number of similarities over time.

\section{Standards}

There have been numerous and almost continuous changes in standards, particularly in the PEFC programs as they seek to compete more effectively in the broader field of certification. Thus, the categories and language of standards have converged in numerous ways. While much of this change has involved gradual 'ratcheting up' (Fung et al 2001, Overdevest 2004) by PEFC members of their environmental standards and occasional addition of social ones, a certain amount has also involved concessions by the FSC to make its program more workable in the face of market challenges. A good example is the adoption of the "percentage claims' policy discussed above. The FSC is also working on streamlined standards for 'small and low intensity forests' (SLIMFS) to reduce costs for small and low income enterprises.

While their standards have come to resemble each other more closely, the different programs are still locked in debates and contests regarding appropriate standards for a number of controversial issues, such as allowable levels of clear cutting, use of pesticides and genetically modified organisms, duties to communities and workers, and the availability of certification information to the public. These are manifested through their contending systems of rules and procedures.

\section{Procedures and Roles}

There has also been considerable convergence on appropriate practices and procedures among the programs. Indeed, since they are essentially extra-governmental regulatory systems, it is not surprising that they have focused a great deal on administrative law questions - i.e., general rules for rule making, adjudication, and information gathering and sharing (see generally, Meidinger 2006). On the whole, the programs have concentrated on their standard setting processes, gradually making them more transparent and participatory. Today they all appear to follow notice and comment procedures similar to administrative agencies in most modern states. Certification programs also increasingly acknowledge duties to respond to public comments and to explain their policies in reasoned ways. Additionally, all of the programs are trying to demonstrate participation by diverse interests in their deliberations. The FSC has gone much farther in this regard than most industry programs, which typically seek to maintain industry control over policy making, but even the industry programs acknowledge a need for broad-based stakeholder participation and seek to foster it in various ways. 
Similarly, much effort has gone into defining appropriate standards, procedures, and accountability structures for certifiers. The programs differ on how certifiers ought to be accredited (with most PEFC programs relying on generalized ISO accreditation agencies and the FSC relying on a program it originally created and later spun off), but they all stress the professionalism and ostensible independence of certifiers and increasingly seek to provide formal auditing systems for certifier decisions. Moreover, following the FSC, the programs are beginning to require that certifiers publish public summaries of their findings, thereby subjecting administrative adjudications as well as rulemakings to public scrutiny. The FSC also requires stakeholder consultations as part of the certification process; the PEFC programs sometimes do, but not always. Hence, while the certification programs stress the importance of defined roles and procedures, they have also blurred the social boundaries between administrators and the public by providing for increased participation, transparency, and responsiveness in rulemaking and adjudication procedures. They thus manifest the dual reliance on expertise and participation that characterizes many Western state regulatory programs today.

Equally importantly, forest certification programs have blurred the boundaries between regulatory programs and firms, both by giving firms a larger official role in defining regulatory standards and by using internal control systems (EMSs) to harness the firms to regulatory goals. This approach no longer treats the firm as a black box responsible simply for producing certain outputs, but rather as part of the regulatory program, with its own organizational and technological resources that can be committed to defining, implementing, and revising regulatory goals (Parker 2000; Coglianese and Nash 2001, Potoski and Prakash 2005, Vandenbergh 2005). In practice, the EMS approach also seems to have the effect of further 'legalizing' forest management operations internally, since certifiers demand to see detailed documentation of planning, implementation, monitoring and correction processes and responsibilities.

\section{Network Organization}

Together, the forest certification programs have consolidated extensive transnational alliances into complex interconnected networks of market participants, environmental and social activists, forestry and certification professionals, and many others (including government officials, as discussed in the next section). These networks have been growing over time and also contending with each other about questions such as the appropriate level of centralization and the nature and role of nodes. 
The FSC arguably initiated this process by bringing environmental, labor, human and indigenous rights groups and others into what had originally been a rather closed circle of professional foresters and landowners or managers. It continues to try to expand its network through strategies such as attempting to appeal to more small landholders and small enterprises through program changes and trying to strengthen its alliances with similar interests in other economic sectors. One of the most important steps in this latter process has been its participation in the International Social and Environmental Accreditation and Labelling Alliance, which also includes low wage labor, organic agriculture, fisheries, and other labeling programs.

Overall, the establishment of the nationally-federated PEFC together with the growing reach and complexity of the FSC have prompted the FSC to move toward decentralization. It has established regional offices and is increasingly focusing on national programs as its fundamental elements (although this strategy remains subject to debate by those who think that the FSC should represent an emerging transnational public, rather than agglomeration of national ones). At the same time, the FSC increasingly sees itself not as a free-standing program, but rather as part of the larger emerging global forest certification and governance system. Its executive director describes FSC's role as being 'a global pacesetter for development of standards and certification' (Leideker 2003).

In sum, while competition among the alternative certification programs originally seemed to imply the fragmentation, and possibly the disintegration of forest certification, that has not occurred. The programs have moved into various kinds of complex linkages as a part of their competition. Formerly hostile groups, particularly professional foresters and land owners, have been turned from outright opponents of forest certification, to proponents, but of their own programs. This inevitably put them in dialogue and mutual surveillance with the FSC program, and seems to have begun a process of investing them in the forest certification system as a whole. Most participants in the certification system seem to be aware that they have developed a considerable amount of mutual interdependence. They all have an investment in the value and validity of certification, and they understand that they will realize some of their goals through their competitors. The proliferation of forest certification has thus helped to consolidate a multi-interest global network engaged in discussions, debates, and institutional competition over appropriate standards and methods for forestry regulation. If this network persists it may constitute an important new type of global regulatory community over time. 


\section{Legalization}

As the above sections make clear, the field of forest certification is strikingly 'legalized'. This term has several salient features here. The first is a heavy reliance on formal rules and definitions of roles. Important issues are routinely resolved and memorialized in rules and decisions. Participants almost universally seek to draw on principles, standards, and rules to define the rights and duties of different kinds of actors, organize their behavior as a whole, and resolve disputes. Most rules and policies are enunciated in formalized procedures and justified in normative terms. Much debate takes place in terms of what constitutes good forest management and a proper allocation of authority, but this debate takes place in the form of contending, heavily legalized regulatory systems. Certification programs have formally differentiated legislative, adjudicative, and administrative authorities, and are giving increasing care to how those authorities are defined, exercised, monitored, and revised. As noted above, the process of legalization is producing a system-wide body of public law stressing public notice and comment proceedings, publicly accessible policies and decisions, participatory procedures and structures, and reasoned explanation. At the same time, it is also producing an extensive body of 'private' law in forest management firms and trading networks, detailing multiple plans, procedures, duties, etc., and linking them back to external requirements, although, as noted above, there is a tug of war between external and internal legalization.

Why legal forms are being so broadly and rapidly extended is unclear. It could be partly a kind of institutional isomorphism. Since other regulatory and certification programs typically take these forms, forest certification programs simply choose to do the same. Or it could be more functional. It is possible that legalization is the best way to achieve the goals of maintaining transnational markets while protecting environmental and social values. Moreover, it could be desirable in part because other programs with this form are seen as legitimate, thus helping to legitimate the new ones (Zablowski 2006). What is clear is that the process is widespread and probably accelerating.

The concept of legalization as used thus far is similar to that of Abbott, et al (2000), except that it is more dynamic and contested. Legalization is not simply a set pattern of institutional characteristics, but also a process of contestation. Here it is helpful to note a further, largely taken-for-granted dimension of legalization in this field - which is that the transnational certification system draws many activities that were previously understood as discretionary, or otherwise outside law, into in the realm of law. Thus, although there are plural legal systems and considerable debate and competition about which rules and whose rules will apply to any given 
activity, rules will indeed apply. These rules will in turn continue to be elaborated and while serving as resources for political contestation. Legalization can thus be understood a strategy for gaining governance capacity.

Finally, it is important to note two additional characteristics of legalization in this field. First, it is very broad and deep, seeking to integrate environmental, economic, and social goals and to link local, national, and transnational domains, as well as civil society, industry, and state organizations. Thus, although there are plural, competing legal systems, together they have great ambitions and increasing reach. Second, the emerging systems are not inherently separate or distinct from state-based law. In fact, as the next section indicates, they are becoming increasingly intertwined with state law.

\section{Relationships to State Governance}

Just as environmentalist-oriented and industry-oriented certification programs appear to be growing together into a larger system, so too does forest certification seem to be growing together with state regulatory and management programs, albeit more slowly and sporadically. The FSC program, although formally independent of states, has as its first principle that forest management operations 'shall respect all applicable laws of the country in which they occur, and international treaties and agreements to which the country is a signatory. . ' Thus, forest certification can be seen as a way of both bolstering state based legal systems and also drawing upon their legitimacy.

\section{Proprietary Activities}

Forest certification has received various kinds of direct resource support from governments. The FSC, for example, received early funding from Austria and later from the Netherlands and several other EU countries (most recently rent-free offices in Bonn for 25 years). Several European countries and numerous municipalities have adopted green procurement policies roughly tracking FSC requirements (Tarasofsky et al 2005). These have prompted the PEFC to change some requirements to make its products eligible for government purchase. So popular and controversial are these procurement programs that the EU is currently working on a policy regarding appropriate rules for government forest products procurement.

Interestingly, a growing number of states, provinces, and municipalities (ranging from Poland to Minnesota to Freiburg, Germany) have had their 
own forests certified. In most cases they do this not in response to allegations that the state forests are failing to meet legal requirements, but rather to demonstrate that government-run forests meet the highest public standards, implicitly acknowledging that governments no longer claim to be the sole arbiters of public duties and legitimacy (see also Scott 2002).

\section{Regulatory Activities}

Some governments are also taking advantage of certification programs in regulating non-state entities. A few (e.g., Guatemala for the Maya Bioreserve) have made certification a requirement of conducting forestry in their jurisdictions. Others (e.g., Bolivia and Estonia) have adopted substantive requirements that are essentially identical to those of certification programs. Typically, this seems to have occurred because the public deliberations on certification standards have directly influenced contemporaneous public deliberations on state standards. When standards are identical or even very similar, it is apparent that certification of a firm can be seen as tantamount to compliance with law. This would also be the case when a certification standard is stricter, but requires compliance with state law and treaties, as is the case with the FSC. Some countries have officially adopted the position that certification of a firm creates a presumption of legal compliance. Given the costs of conducting inspections, it seems likely that other countries will follow it implicitly (see generally, Meidinger forthcoming).

Certification programs are also trying to position themselves to shape state regulatory requirements in the future. International trade law requires WTO members to use recognized international standards in adopting internal technical regulations and standards applicable to internationally traded goods. ${ }^{1}$ Over time it seems likely that international trade law will promote the absorption of certification standards into state legal systems.

Certification standards are also likely to be pulled into state legal systems indirectly through such channels as tort standards for reasonable care and administrative expectations of best practices as interpreted by inspectors. These are slow, and sometimes empirically intricate processes, however, and no substantial research seems to have addressed them to date.

Finally, certification programs are closely interconnected with a recent intergovernmental initiative to fight illegal logging in tropical countries. Spurred by a 1998 G-8 Summit calling for governments to join forces in dealing with the problem, the Forest Law Enforcement, Governance and Trade Action Plan (FLEGT -- a European program), and other similar regional and bilateral programs, seek to eliminate access to developed

\footnotetext{
${ }^{1}$ E.g., Article 2.2, Technical Barriers to Trade (TBT) Agreement.
} 
markets of legally produced timber. Thus timber imported from threatened forests must be certified as legal, and existing forest certification programs offer a way of both providing such certification and possibly leveraging improved forest management generally.

At a broad scale, it is arguable that the certification programs are giving shape to a new transnational forest regulatory and governance regime, one that is centered in the competition among certification programs, but also involves continuing monitoring and participation by governments, corporations, and NGOs at the transnational, national, and local levels. The emerging regime centers on plural and competing, yet interconnected, systems of rules and duties, draws in and yet requires changes in state legal systems, and thus both strengthens and threatens to displace them, depending on the particular situation.

\section{Other Sectors}

The analysis thus far has concentrated on forestry, begging the question whether the competitive legalizatation that it describes is exceptional or more general. This question is not easy to answer at this stage, both because developments in every sector are highly complex and because relatively little research along the lines outlined above has been carried out. This paper therefore makes some tentative comparisons with other sectors that are necessarily subject to great elaboration and revision in the future.

\section{Organic Agriculture}

Organic agriculture certification was a direct precursor of forest certification, since some of the FSC founders had prior experience with organic certification. Like the FSC, the organic agriculture movement had its roots in efforts to reform natural resource management - in this case stopping the use of chemical pesticides, herbicides, and fertilizers, avoiding monocultures, protecting ecological systems, and generally keeping people and animals healthier (Conford 2001). Unlike forest certification, however, this movement was premised on a belief that adherence to its principles would directly benefit end consumers, since organically grown foods were believed to be healthier and safer. Thus, it fit better with traditional standard setting and certification processes, which are also premised on the belief that certified products will perform better than uncertified ones. Still, it was partly a moral and ethical movement aimed at defining a right way of living.

While the history of the organic agriculture is far too complicated to summarize here, it can be roughly sketched in several phases. In the first 
half of the 20th century reformers developed the rationale for organic agriculture and founded various model farms and communities. In the 1960 s and 1970s these foundations combined with several chemical scares and the environmental movement to catalyze the first organic certification movement. Interestingly, although a German program dated from the 1920s (Coleman and Reed, this volume), most non-governmental certification programs were founded almost simultaneously at the state and international levels. Thus, organic certification programs in California, Oregon and Washington were immediately complemented by the International Federation of Organic Agriculture Movements (IFOAM), although IFOAM only managed to promulgate its first standards in 1980 (Bolster 2006).

Organic certification in the US has long been a competitive field, and practices evidently have varied greatly among certifiers and jurisdictions. IFOAM finally launched an accreditation program in 1992, but by this time many certifiers had established business and chose not to seek IFOAM accreditation. Certification schemes and organizations proliferated, creating an increasingly complex and inconsistent patchwork that came to be understood as a significant problem.

This 'tower of Babel' paved the way for the US Organic Foods Production Act (OFPA) in $1990 .^{2}$ While mandating national standards for organic agriculture certification, the OFPA failed to define 'organic', leaving it to the U.S. Department of Agriculture (USDA) working with a nongovernmental advisory committee, the National Organic Standards Board (NOSB). The Act also requires that any food carrying the label 'organic' be certified as such by an organization that has undergone accreditation by a division of the USDA, rather than the IFOAM affiliated International Organic Accreditation Service. Most of the accredited certifiers are private organizations, although some are states and some are based in foreign countries (Coleman and Reed, this volume).

Overall, the standards promulgated through the US regulatory system tend to be lenient. The USDA has sided with large-scale agriculture and overridden a number of NOSB recommendations by allowing the use of genetically engineered crops, application of sewage sludge to crops, and use of irradiation in producing foods that can be labeled 'organic' (Bolster 1996). Moreover, the US standard does not require ecological practices beyond limitations on ingredients and entirely ignores concerns about the treatment animals.

\footnotetext{
${ }^{2}$ Food, Agriculture, Conservation and Trade Act of 1990, Pub.L. No. 101-624, Title XXI, Organic Food Production Act, 104 Stat. 3359, 3937 (1990), 7 U.S.C. § 6501-6523.
} 
Perhaps the most portentous effect of the federal program is to preemptively define the meaning of 'organic' in US commerce - including for imported foods - at a relatively low level. Farmers are free to exceed the standard if they wish, and states or other programs may set stricter standards, but they are forced to use additional labels or information to communicate that fact. Similar patterns are evident internationally, where a number of major national governments have largely ignored central elements of the IFOAM standards, and even those of countries they trade with, in promulgating their own. IFOAM is currently working on a major revision of its standard, with the hope that it can shape the development of future governmental and other standards by leading the way in defining core principles and concepts. It will be an interesting test of the transnational regulatory system to see whether and how well governments respond to this IFOAM initiative and to each other's standards. International trade law may provide at least some positive incentive to do so, since it prohibits technical requirements for internationally traded products that are 'unnecessary obstacles to trade' or 'more traderestrictive than necessary to fulfill a legitimate objective' and also enjoins governments to use recognized international standards when possible. ${ }^{3}$

\section{Fisheries}

Although fisheries comprise a large part of the earth's surface, the social world of fisheries regulation is considerably smaller than that of agriculture regulation. Most ocean fisheries have long been in decline due to heavy fishing pressure and deteriorating environmental conditions. In 1997 WWF joined with Unilever, one of the world's largest buyers of fish, to establish the Marine Stewardship Council (MSC). Modeled in large part on the FSC, the MSC defines itself as 'an independent, global, non-profit organization whose role is to recognize, via a certification program, well-managed fisheries and to harness consumer preference for seafood products bearing the MSC label of approval'. The MSC standards are largely environmental and operational, omitting social issues. The MSC has accredited a small group of certification organizations, some of which concentrate on fisheries and others on market chains carrying certified fish. Approximately eighteen fisheries have been certified to date, with a similar number under consideration.

In certifying whole fisheries the MSC is in part certifying governments, since their cooperation and effective enforcement is essential to curbing the tragedy of the commons that typically affects fisheries. Although it provides for public comment and participation in standard setting and certification processes, the MSC has a much more limited stakeholder structure than either the FSC or IFOAM, and seems to operate on a more

\footnotetext{
${ }^{3}$ Article 2.2, TBT Agreement.
} 
technocratic basis. Its influence on world fisheries governance is more preliminary and unclear as well. But at this point it seems plausible that the MSC process could eventually stimulate the production of relatively widely accepted standards and procedures for certifying sustainable fisheries - provided of course that certified fisheries in fact prove sustainable.

\section{Apparel}

Global apparel markets have long been seen both as exacerbating mistreatment of third-world workers and as offering a possible way to improve their conditions by making revenues contingent on proper treatment of workers. The 1980s brought a flurry of corporate codes of conduct by branded companies in response to highly publicized cases of worker abuse tied to their brands. These were often linked to actual or threatened consumer boycotts. In the late 1990s three separate apparel certification programs were founded, mainly with the goal of improving the consistency and implementation of codes of conduct. Two of them, Social Accountability International (SAI) and the Fair Labor Association (FLA), were primarily the offspring of NGOS and governments, while the third, Worldwide Responsible Apparel Production (WRAP), was founded by the industry (Bartley 2003). SAI and WRAP certify individual factories, whereas FLA certifies entire supply chains. Competition among the programs has been intense and contentious at times.

The apparel certification programs have been able to draw on labor standards developed by governments and intergovernmental organizations, mainly the UN-based International Labor Organization (ILO). Still, a high level of contention about proper standards persists. As in organic certification, there is considerable disagreement among governments, and between governments and certification programs. Most governments of third world countries have been anxious not to be seen as havens for labor abuse, but also not to be forced into strict labor standards that might reduce their comparative advantage in this highly pricecompetitive and volatile industry. These complexities combined with the inherent difficulty of regulating labor conditions in far-flung and rapidly rotating factories make it clear that achieving effective global governance over labor conditions in apparel production will be enormously difficult. While the certification programs have led to notable improvements in particular cases, it is difficult to document widespread effects. Nonetheless, one school of thought strongly argues that the presence of certification programs has helped to 'ratchet up' worldwide labor standards generally, and it does seem plausible that the overall labor situation would be even worse without apparel certification programs (Fung et al 2001). 


\section{Mining}

Mining is one of the most intriguing sectors in which regulation by certification has been attempted. Particularly in developing countries, the mining industry has a reputation for being exploitive in the fullest sense of the word. And yet, this dubious reputation has also been a source of regulatory leverage in the global market, as mining companies seek to avoid campaigns like the recent one against 'blood' or 'conflict' diamonds. Mining certification began in the African diamond industry, after several NGOs demonstrated that rebel groups were using revenues from diamond mines to fuel brutal civil wars in Sierra Leone, Angola, and Congo (Campbell 2002). In the 'Kimberley Process' they were able to cooperate with business interests (mainly the virtual monopolist, DeBeers) and governments to establish a program for certifying diamonds as not having helped to finance civil wars (Kimberly Process). The process took about three years and seems to have produced a well functioning certification program. DeBeers used its virtually unique expertise to work out many of the operational details of the program and the main NGO involved (Global Watch) was able to successfully push for external auditing (Kantz 2006). The governments directly affected were very supportive of the program because it helped reduce rebel activity and challenges to their authority.

Since the Kimberly Process Certification Program was created to address a specific, relatively narrow problem, the question remains whether certification programs can be instituted to address the larger challenges of environmental and community protection posed by mining. At present the sector involves a hodgepodge of individual company codes of conduct (e.g., Newmont Mining 2006), limited subsector initiatives (e.g., CRPP 2006), and proposals for sector-wide certification programs (e.g., MCEP 2006). The most important of the sector-wide proposals, the WWFsupported Mining Certification Evaluation Project (MCEP 2006), concludes that there is enough convergence in the various initiatives to support the establishment of an industry-wide third-party certification program involving broad stakeholder participation and covering environmental, human rights, worker health and safety and community issues, among others. Whether such a program is created remains to be seen, but if it is, it may be a quite remarkable extension on all that has come before it.

\section{Impacts}

The first question commonly raised about regulatory systems like the ones described above is how effective they can be. They rely primarily on 'soft' law rules and quasi-voluntary implementation structures, meaning that states play a relatively small role in making and enforcing the rules. Thus, if certification-centered regulation is effective, the primary mechanisms are 
not likely to be those associated with state-based legal systems. While it is too early to draw strong conclusions on the question of efficacy, there is a growing body of research suggesting that certification has significant effects on management practices as well as larger governance structures, certainly in the case of forestry (Bass et al 2001; Cashore et al 2006), probably in the cases of organic agriculture (e.g., Allen and Kovach 2000; Greer 2002; Marshall and Standifird 2005) and apparel (Elliott and Freeman 2003; Fichter and Sydow 2002), and likely in the future case of mining certification (MCEP 2006).

The largest amount of research has been done in the field of forest certification. A recent set of systematic studies of forest certification in sixteen developing and transitioning countries found a host of effects on forest management and local governance institutions (Cashore et al 2006). Most cases indicated that the adoption forest certification has led to improved environmental management practices in the industry, including better inventorying and planning, silvicultural practices, biodiversity protection, environmental monitoring, and training. In addition, certification has sometimes stimulated the introduction of entire new concepts, such as the Estonian 'spring truce', a time during which forestry is curtailed so as to avoid disturbing reproduction patterns of forest fauna. Forest certification has also led to improved labor conditions in many cases, ranging from the provision of protective clothing and shielded tools to better training and sanitary conditions.

Equally importantly, the introduction of forest certification has led to various 'network effects' in local governance structures. In some countries with relatively closed governance structures the introduction of forest certification has led to the inclusion of previously excluded groups (typically environmental, labor and community groups) and seems also in some cases to have rebalanced power away from government officials and industry. The amount of change varies greatly among cases, however, and it is impossible to know at this stage how persistent these changes will be.

To date, the effectiveness of certification programs in forestry as well as other sectors has depended heavily on the ability of activist regulatory entrepreneurs to use market chains to both pressure and monitor changes in forestry practices. Their capacity to do so is unlikely to continue indefinitely. Moreover, although perhaps to a lesser extent in the case of agriculture, global inequalities are an important part of program effectiveness. Thus, forest, apparel, and mining certification affect practices in developing countries because failure to achieve certification portends potentially serious losses of revenues from developed countries. 
If international income inequalities decline over time, domestic demand for certified products in developing countries will have to rise to maintain market pressure and support for certification requirements, unless they have already been incorporated in a broader set of regulatory structures.

The mechanisms of certification's efficacy go well beyond market pressure and surveillance; it seems clear that they must operate through the general process of institutionalization, wherein changed practices become routine and taken-for-granted over time, ultimately shifting cultural understandings of appropriate behavior. While it is apparent from the general literature on institutionalization (e.g., DiMaggio and Powell 1983; Colyvas and Powell, 2006) that this process is likely to occur, there has been little research to date documenting its dynamics in certification based regulatory systems. It seems reasonable to expect that insitutionalization will operate through a variety of pathways, including routine interactions within firms and among wood producers, processors, and buyers as well as changing assumptions in professional education. It will be important to try to understand how the tendency toward legalization - i.e., the formal expression of rights, duties and expectations together with the development of increasingly elaborate justificatory rationales and implementation institutions -affects institutionalization. The same goes for the effect of mutually reinforcing legal orders slowly bringing extragovernmental orders into alignment with governmental ones. Ultimately, if some critics of ostensibly technocratic standard setting processes are correct, the effects should be visible as changes in the very identities of the participants in the regulatory systems (Wood 2004).

Finally, to say that certification systems have significantly affected resource management and governance structures and that they are expanding and linking up with each other and with state systems is not to say that they are adequate to handle the problems they seek to address. Each of the certification centered regulatory systems discussed in this paper has been vehemently criticized as inadequate to the task at hand. Some critics even argue that they are counterproductive, since they may give the impression of offering solutions without the reality, thus diverting attention and resources from 'real' solutions (e.g., Latin 2005). These criticisms and the underlying questions they pose cannot be firmly answered at this stage, since the systems are still in formative stages and have not been carefully studied. Furthermore, the question of adequacy demands a referent - adequate in relation to what? And here there is a huge problem, because the perfect 'hard' regulatory systems do not exist and appear to have no prospect of coming into being in the near term. Even so, however, eventually this question will have to be addressed head on: has the turn toward certification based regulatory systems been an 
effective move, or a fundamental mistake? Fortunately or unfortunately, that time has not yet arrived. Moreover, part of the answer will undoubtedly depend on questions beyond simple effectiveness.

\section{Broader Implications}

While the regulatory systems described in this paper employ conventional standard setting and certification techniques, they simultaneously constitute new institutional arrangements with potentially significant implications for law, society, and their changing relationship.

\section{$\underline{\text { Law }}$}

The argument of this paper is that emerging certification-based regulatory systems entail a particular and somewhat novel kind of law making. Even prior to certification programs, the emergence of global markets typically generates legal pluralism on its own, since different parts of the expanded social space delimited by the market are subject to different territorially based legal regimes. At the same time, actors in one part of the market are both implicated and increasingly understood as having interests in actions in other parts, as the results of their transactions have effects there. Global certification programs are efforts by self-appointed non-state officials to bring these interests and effects into a common legal regime.

Yet in the cases discussed above, the creation of one certification regime typically provokes establishment of at least one other, and often significant developments in state regulation as well, all of them with increasingly transnational reach. Thus, at any given point in the global market chains discussed above there are likely to be at least three operative legal orders, an NGO-oriented one, an industry-oriented one, and probably a state one as well.

These orders are neither independent of each other nor static. Instead, they interact and compete, generating a larger governance structure and associated legal system that grow increasingly dense and yet unsettled at the same time, at least in the short run. To some extent, as discussed above, the competing systems may tend toward convergent standards and institutions, but the evidence for this proposition is not persuasive at this point. The case of organic agriculture, for example, suggests persistent and possibly expanding divergence among regimes, and this despite the pressures of expanding international trade for harmonization. Thus, at least in the near term, there is continued plurality and contestation. While there may be 'more' and more detailed law, and while it may permeate more social spaces, it is also deeply contingent and contested. So much so, that it seems likely to engage more and more 
actors in each sector in the process of defining and redefining the rules, and to face them with repeated choices about which rules to accommodate.

Just as the spread of certification may bring those who would traditionally have been low-level legal functionaries or addressees into active law making roles, so also it may turn those who would have been primarily lawmakers into legal entrepreneurs. The executive director of the FSC, for example, sees the FSC as fundamentally a change agent, rather than a certifier of good practice. To him the critical challenge facing the FSC is that of 'finding new objectives for the future' (Liedeker 2002). Leaders of industry based certification organizations portray their programs in similar ways. Virtually in unison, they talk about the importance of continuous improvement, expanding public participation, and building new relationships across constituencies. Law making as it has been described here is very much an entrepreneurial activity.

Much work remains to be done in describing the dynamics of these emergent legal systems. As suggested above, it is possible that they represent a distinctive form of law, one in which competition and change have taken on new importance while stability and consistency have receded. The traditional legal forms of (1) defining rights and duties through rules (2) made through increasingly participatory, transparent, and regularized procedures (3) implemented by specialized officials and (4) justified in terms of normative principles are retained. Yet, change is built into the system through both traditional processes of legislation and adjudication and new ones of competition and contestation before a public that remains amorphous, segmented, and very much under construction.

\section{Society}

If the above depiction of emerging legal systems is at all accurate, it poses many important questions about what kind of society they will foster and support. One of the most obvious is the very definition of society. The Westphalian system of international law presumes national societies whose governments negotiate relationships with each other and promulgate international rules through treaties, conventions, mutually accepted customs, and the like. Clearly, however, global markets place pressure on that conception, since growing numbers of people are in more regular contact with 'foreigners' than with many people in their own countries, may have more in common with those foreigners, and often work out rules to organize their interactions without significant state involvement. Moreover, the vision of national societies has always been problematical in many states because they contain distinct communities 
with different, often inconsistent legal traditions, most of which have been suppressed.

Certification-based regulatory systems seem more sensitive to such differences than are traditional national and international legal systems. They appear to incorporate normative discourses such as human and community rights and environmental protection much more readily than the Westphalian system, and they officially value community protection and participation. Moreover, their very existence as alternative legal orders is a powerful indicator of the fact that people in the modern world participate in and negotiate their way through multiple legal communities.

Yet certification-based regulatory systems may also have widespread homogenizing effects over time. Their competition to define common standards seems to have inherently centralizing tendencies. While it is also tempered by a competition to fit local circumstances, those local circumstances are for the most part filtered through 'practical realities' defined by the global economy. Pressures to accommodate the global market make many traditional modes of existence less feasible by the day, and certification systems seem to facilitate that trend, with their emphasis on standard methods of operation, management systems, audited accountability, and so on.

The problem is not purely an anthropological one, however; the question is not simply whether traditional societies can be 'preserved'. Rather, it is whether they can participate in global commerce in ways that sustain their capacity to define important terms of their own lives. If certification based regulatory systems are indeed sufficiently responsive to diverse communities to facilitate this process, they may help over time to construct a world society that both preserves spaces for distinctive communities and provides forums for interaction and negotiation among them.

At present, transnational society is organized along several different lines, including economic sectors, states, and communities and peoples. The interaction among these contending organizational orders is disjointed at best. Whether one sees the emerging system as a heterarchy (e.g., Ehrenreich et al 1995) or a polyarchy (e.g., Dahl 2003; Cohen and Sabel 2001) or something else, the nature of the interaction among the orders is amenable to many alternatives and carries many possible normative implications.

Perhaps the most vexing normative implication is the thorny problem of democracy. The emerging regulatory systems are not representational in any traditional sense of the concept. Rather, they rely on various 
procedural devices such as transparency, expanded participation, and reasoned explanation as substitutes, together with relatively open interactions among the plural social ordering structures noted above. The problem is, what kind of democracy, if any, is possible in these circumstances? The response up to this point seems to be a conceptual hodgepodge, with discursive and structural elements linking in multiple and shifting forms. A particularly notable feature on the discursive side is the reliance by many certification programs on adumbrating concepts tied to what some commentators have described as 'high moral authority' (Keck and Sikkink 1998; Wapner 1995). Concepts such as human rights and ecosystem health provide powerful reference points that help to orient the systems, even as they remain subject to continuing elaboration and contestation through economic, governmental, and civil society ordering systems (e.g., Baxi 2005).

Whether the emerging regulatory ensembles will learn to perform in ways that compose a global democracy will depend on simultaneous development of new theoretical and empirical understandings that inform and drive each other forward. Perhaps they will learn to implement new forms of cosmopolitan democracy (Held 2000), and perhaps they will find areas of 'overlapping consensus' among peoples by settling on 'reasonable pluralism' (Rawls 2001). Or perhaps they will converge around quite different governance structures that may or may qualify as 'government by the people'. No doubt we will engage in many debates on this question in years to come.

\section{References}

Abbott, K.W., Keohane, R.O., Moravcsik, A. Slaughter A.-M., and Snidal, D. (2000) 'The Concept of Legalization', International Organization, 54(3): 401-419.

Allan, P and Kovach, M (2000) 'The Capitalist Composition of Organic:

The Potential of Markets in Fulfilling the Promise of Organic Agriculture', Agriculture and Human Values, 17: 221-233.

Bartley, T. (2003) 'Certifying Forests and Factories: States, Social Movements, and the Rise of Private Regulation in the Apparel and Forest Products Fields', Politics \& Society 31(3): 433-464.

Bass, S, Thornber, K, Markopoulos, M, Roberts, S and Grieg-Gran, M (2001) Certification's Impacts on Forests, Stakeholders, and Supply Chains (London: International Institute for Environment and Development). 
Baxi, Upendra (2005) 'Market Fundamentalisms: Business Ethics at the Altar of Human Rights,' Human Rights Law Review, 5(1): 1-26.

Black, J. (2002) 'Regulatory Conversations', Journal of Law and Society 29: 163-196.

Bolster, T. (2006) 'Governing Organic', Independent Study, SUNY Buffalo Law School, January 23, 2006. (Copy on file with author).

Brown, K. (2001) 'Cut and Run? Evolving Institutions for Global Forest Governance', Journal of International Development 13: 893-905.

Campbell, G. (2002) Blood Diamonds: Tracing the Deadly Path of the World's Most Precious Stones. Boulder: Westview Press.

Cashore, B, Gale, F, Meidinger, E and Newsom D (eds) (2006) Confronting Sustainability: Forest Certification in Developing and Transitioning Countries, (New Haven: Yale Forestry School).

Cashore, B., Auld, G. and Newsom, D. (2003) 'The United States' Race to Certify Sustainable Forestry: Non-State Environmental Governance and the Competition for Policy-Making Authority,' Business and Politics 5: 219-259.

CJRP (2006) Council for Responsible Jewelry Practices: What We Stand For, http://www.responsiblejewellery.com/what.html

Coglianese C. and Nash, J. (eds.) (2001) Regulating from the Inside: Can Environmental Management Systems Achieve Policy Goals? Washington, DC: Resources for the Future.

Cohen J. and Sabel, C. (1997) 'Directly-Deliberative Polyarchy' European Law Journal 3:313-342.

Colyvas, J. and Powell, W.W. (forthcoming) 'Roads to Institutionalization,' in Barry Staw (ed.) Research in Organizational Behavior, 01/06 at http://www.stanford.edu/group/song/papers/colyvas powell.pdf

Conford, P. (2001) The Origins of the Organic Movement, Edinburgh: Floris Books.

Dahl, R.A.,, (2003) 'Can International Organizations be Democratic? A Skeptic's View, in Held, D. and McGrew A., (eds.) The Global 
Transformations Reader: An Introduction to the Globalization Debate, London: Polity Press.

DiMaggio, P. and Powell, W.W. (1983) 'The Iron Cage Revisited: Institutional Isomorphism and Collective Rationality in Organizational Fields,' American Sociological Review 48(2): 147-160 (1983).

Ehrenreich, R.M., Crumley, C.L. and Levy, J.E. (eds.) (1995) Heterarchy and the Analysis of Complex Societies, Arlington, Va.: American Anthropological Association.

Elliott, K and Freeman, R (2003) Can Labor Standards Improve Under Globalization? Washington: Institute for International Economics.

Fichter, M and Sydow, J (2002) 'Using Networks Towards Global Labor Standards? Organizing Social Responsibility in Global Production Chains', Industrielle Beziehungen, 9(4): 357-380.

FSC (2006) 'Forest Stewardship Council Governance' http://www.fsc.org/en/about/governance

Fung, A. O'Rourke, D. and Sabel, C (2001) Can We Put an End to Sweatshops? Boston: Beacon Press.

Gale, F. (1998) The Tropical Timber Trade Regime, New York: St. Martins.

Greer, A (2002) 'Policy Networks and Policy Change in Organic Agriculture: A Comparative Analysis of the UK and Ireland, Public Administration, 80(3): 453-474.

Humphreys, D. (1996) Forest Politics: The Evolution of International Cooperation, London: Earthscan.

ISO (2006) International Organization for Standardization, 'ISO 9000 and 14000 - in brief' http://www.iso.org/iso/en/iso9000-14000/understand/inbrief.html

Kantz, C. (2006) 'Public-Private Partnerships in the South: The Case of the Kimberley Process', paper presented to the International Studies Association, San Diego, March 25, 2006. http://convention2.allacademic.com/index.php?cmd=Download+Docum ent\&key=unpublished manuscript\&file index=1\&pop up=true\&no click 


\section{key=true\&attachment style=attachment\&PHPSESSID $=2 \mathrm{bc} 3 \mathrm{bd8e} 41 \mathrm{a} 6$ $\underline{526 \mathrm{~b} 4 \mathrm{~d} 34 \mathrm{~b} 2815 \mathrm{ca} 240 \mathrm{f} 3}$}

Keck, Margaret E., and Kathryn Sikkink. 1998. Activists Beyond Borders: Advocacy Networks in International Politics. Ithaca: Cornell University Press.

Kimberly Process (2006) http://www.kimberleyprocess.com:8080/site/

Latin, H (2005) 'Is FSC Helping or Hurting Forest Conservation,' email to the envlawprofessors list serve, John Bonine, moderator, University of Oregon. Message dated June 29, 2005. Copy on file with author.

Marshall, R.S. and Standifird, S.S. (2005) 'Organizational Resource Bundles and Institutional Change in the U.S. Organic Food and Agricultural Certification Sector, Organization \& Environment, 18(3): 265-286.

MCEP (2006) Mining Certification Evaluation Project Final Report, http://www.minerals.csiro.au/sd/Certification/MCEP Final Report Jan2 $\underline{006 . p d f}$

Meidinger, E. (forthcoming) 'Multi-Interest Self-Governance through Global Product Certification Programs', in Olaf Dilling, Martin Herberg, and Gerd Winter (eds.) Responsible Business? Self-Governance in Transnational Economic Transactions.

Meidinger, E. (2006) 'The Administrative Law of Global Private-Public Regulation: the Case of Forestry', European Journal of International Law, 17:47-87.

Meidinger, E. (1985) 'On Explaining the Development of 'Emissions Trading' in US Air Pollution Regulation', Law \& Policy, 7(4):447-479.

MSC (2006) Marine Stewardship Council, Fisheries, at http://www.msc.org/html/content 463.htm

Newmont Mining (2006) Five Star Management Program, http://www.newmont.com/en/social/fivestar/management/index.asp

Overdevest, C. (2004) 'Codes of Conduct and Standard Setting in the Forest Sector: Constructing Markets for Democracy?' Industrial Relations, 59:172-195. 
Parker, C.(2000) 'Reinventing Regulation Within the Corporation: Compliance-Oriented Regulatory Innovation' Administration and Society 32(5): 529-565.

PEFC (2006) PEFC Members and Schemes http://www.pefc.org/internet/html/members schemes/4 1120 59.htm.

Potoski M. and Prakash, A. (2005) 'Covenants with Weak Swords: ISO 14001 and Facilities' Environmental Performance,' Journal of Policy Analysis and Management, 24(4): 745-769.

Rawls, J. (2001) The Law of Peoples, Cambridge: Harvard University Press.

Sasser, E. (2002) 'Gaining Leverage: NGO Influence on Certification Institutions in the Forest Products Sector, in L. Teeter, B. Cashore, and D. Zhang (eds.) Forest Policy for Private Forestry (Oxford: CABI Press).

Scott, C. (2002) 'Private Regulation of the Public Sector: A Neglected Facet of Contemporary Governance', Journal of Law and Society, 29: 56-76.

Szablowski, D. (2006) 'Of Models and Mimics: Legitimation Strategies and the Constitution of Transnational Legal Authority,' Paper presented at the International Studies Association Conference, San Diego, March 2225, 2006.

Szablowski, D. (2004) Legitimacy and Regulation in the Global Economy: Legal Mediation of conflicts Between Communities and Transnational Mining Companies, Ph.D. Dissertation in Law, York University, Toronto, Ontario.

Tarasofsky, R. G., Mechel, F., and Sprang, P. (2005) 'Public Procurement and Forest Certification: Assessing the Implications for Policy, Law, and International Trade,' Draft report to Chatham House and Ecologic. http://www.ecologic.de/download/projekte/900949/933/draft_report_050602.pdf

Vandenbergh, M, (2005) 'The Private Life of Public Law,' Columbia Law Review, 105: 2029-2096.

Wapner, P. 1996. Environmental Activism and Worlds Civic Politics, Albany, State University of New York Press. 
Wood, S (2004) 'Three Questions About Corporate Codes:

Problematizations, Authorizations and the Public/Private Divide' in Wesley Cragg, ed., Ethics Codes: The Regulatory Norms of a Global Society?, Aldershot, UK: Edward Elgar, pp. 245-288. 